\title{
Üst Düzey Sporcuların Egzersiz Bağımlılık Düzeylerinin İncelenmesi
}

\author{
Havva Gizem DEMIREL ${ }^{1 *}$ (i) \\ ${ }^{1}$ Gazi Üniversitesi, Eğitim Bilimleri Enstitüsü, ANKARA \\ ${ }^{2}$ Gazi Üniversitesi, Spor Bilimleri Fakültesi, ANKARA
}

Halil İbrahim CicioĞLU² $\mathbb{D}$

\section{DOI: 10.31680/gaunjss.737158}

Orijinal Makale / Original Article

Geliş Tarihi / Received: 17.06.2020

Kabul Tarihi / Accepted: 13.08.2020
Yayın Tarihi / Published: 14.09.2020

\section{Öz}

Araştırmada üst düzey sporcuların egzersiz bağımlıı̆̆ düzeylerinin incelenmesi amaçlanmıştır. Araştırma, 66'sı takım (basketbol, Amerikan futbolu) ve 94'ü bireysel (atletizm, güreş) olmak üzere toplam 160 (35 kadın, 125 erkek) milli takımda yer alan üst düzey sporcu üzerinden yürütülmüştür. Araştırmada "Kişisel Bilgi Formu" ve "Egzersiz Bağımlılığı Ölçeği (EBÖ)" kullanılmıştır. Araştırmanın modeli, nicel araştırma yöntemlerinden betimleyici bir tarama desenidir. Araştırmada pearson korelasyon katsayısı, Mann Whitney $U$ testi, Krusal-Wallis testinden yararlanılmıştır. Yapılan analiz sonucunda, EBÖ ile katılımcıların yaş değişkeni arasında istatiksel anlamda anlamlı bir ilişki bulunmamıştır. Branş, cinsiyet maddi gelir değişkenleri ile EBÖ alt boyutları arasında istatiksel olarak anlamlı bir farklılık saptanmamıştır. Katılımcıların spor yaşına göre; 'Aşırı Odaklanma ve Duygu Değişimi' alt boyutunda pozitif yönde düşük düzeyde anlamlı bir ilişki saptanmıştır. Sonuç olarak; üst düzey sporcuların, spor yaşı, branş, cinsiyet, maddi gelir değişkenleri ile egzersiz bağımlılığı ölçek ve alt boyutları toplam puan ortalamalarına bakıldığında 'bağımlı' grupta yer aldıkları tespit edilmiştir. Buna sebep olarak; yıllar boyunca düzenli ve profesyonel anlamda spor yapan sporcuların başarılarıyla doğru orantıda yükselen performansları, bireyleri daha fazla egzersiz yapmaya motive ederek, yapmış oldukları egzersizin bağımlılık oluşturabileceğini fark etmelerine engel olabileceği düşünülmektedir.

Anahtar Kelimeler: Üst düzey sporcu, spor, egzersiz bağımlılı̆ı

\section{Investigation of Exercise Addiction Levels of Senior Athletes}

\begin{abstract}
The aim of the study was to examine the levels of exercise addiction of senior athletes. The research was conducted on the top athletes in the national team of 160 (35 women, 125 men), 66 teams (basketball, American football) and 94 individually (athletics, wrestling). In the research, "Personal Information Form" and "Exercise Addiction Scale (EBÖ)" were used. The model of the research is a descriptive survey pattern from quantitative research methods. Pearson correlation coefficient, Mann Whitney $U$ test, Linear-Wallis test were used in the study. As a result of the analysis, there was no statistically significant relationship between EBÖ and the age variable of the participants. No statistically significant difference was found between the branch, gender, material income variables and the EBD sub-dimensions. According to the sports age of the participants; A low level of meaningful relationship was found positively in the sub-dimension of "Excessive Focus and Emotion Change". As a result; When the average age of the athletes, sports age, branch, gender, material income, and exercise addiction scale and sub-dimensions were examined, it was determined that they were in the 'dependent' group. As a reason; It is thought that the athletes who have been exercising regularly and professionally over the years, rising in direct proportion to their success, may motivate individuals to exercise more and prevent them from realizing that their exercise may be addictive.
\end{abstract}

Keywords: Senior athlete, sports, exercise addiction

\footnotetext{
* Sorumlu Yazar: Havva Gizem DEMIREL

Yüksek lisans tezinden üretilmiştir.
} 


\section{Giriş}

Egzersiz, fiziksel aktivitenin alt sınıfı olarak kabul edilen, planlı, yapılandırılmış, istemli, fiziksel uygunluğun bir ya da birkaç unsurunu geliştirmeyi amaçlayan sürekli aktiviteler bütünüdür. Egzersizin, duygu durum hormonlarını etkilediği, özellikle endorfin üretimini artırdığı ve bunun sonucu olarak bireye kendini daha mutlu ve daha iyi hissettirdiği yapılan çalışmalarda ortaya konulmuştur (Adams, Miller ve Kraus, 2003). Ancak bazı bilimsel araştırmalar kontrol edilemeyen oranlarda yapılan egzersizin zararlı olabileceği ve bağımlılık yaratabileceği konusunda veriler sunmaktadır (Griffits, 2000; Szabo, 2000; Szabo,1998; Yates,1991). Sağlıklı ve uzun yaşamın temel anahtarına sahip olabilmek için yapılan egzersizin sıklığının belirlenememesi, abartıya kaçırılması durumunda insan vücuduna zararlı hale gelebilme boyutunu göz ardı etmemek gerekmektedir. Fiziksel egzersizlerin, bireylerin depresyon düzeylerinde düşüş sağlaması birçok araştırmacının depresyon tedavisinde fiziksel egzersizlerin kullanılmasını tavsiye ettiği çalışmalara rastlanılmaktadır (Klein, 2005). Araştırmacıların iddialarına göre; kumar oynamak, yemek yeme, cinsel aktiviteler, bilgisayar oyunları ve internet kullanımı gibi davranışların yanında egzersiz yapmanın da bağımlılık haline gelebilmesi mümkündür (De Coverly ve Veale, 1987).

Egzersiz, bireylerin fiziksel, zihinsel, duygusal ve sosyal yönden sağlıklı olabilmeleri açısından önemli bir rolü bulunduğu gibi, aşırı düzeyde ve kontrolsüz bir şekilde yapılması, beklenen fayda yerine egzersiz bağımlılı̆̆ gibi olumsuz sonuçları doğurabilmektedir (Çetin vd., 2020). Egzersizin birey üzerindeki kötü etkilerini belirtirken ele alınan önemli olgulardan biri egzersiz bağımlılığıdır. Egzersiz bağımlılığı, egzersizin "karanlık yüzü” olarak isimlendirilen, bireyin sağlığını kötü şekilde etkileyen bir ruhsal hastalıktır (Tekkurşun Demir ve Türkeli, 2019). Bağımlılık; Orford'a göre 'aşırı isteklilik' olarak tanımlanmıştır (Orford, 1985).

Egzersiz bağımlıığı; zamanı fiziksel aktivite ile geçirmeye aşırı istekli olma, engellere rağmen kontrolsüzce aşırı egzersiz yapma durumudur (Hausenblas ve Downs, 2000). Egzersiz bağımlılığı, pozitif ve negatif bağımlılık olarak incelenmektedir. Araştırmacılar egzersiz bağımlılığında, negatif bağımlıığı; aşırı egzersiz yapan bireyin egzersiz yapamadığında kaygı, depresyon, sinirlilik, uykusuzluk gibi sorunlar yaşaması, pozitif bağımlılığı ise; bireyin yaşantısı içerisinde karşılaştığı zorluklarla başa çıkmak için aşırı egzersiz yapması olarak iki farklı formda değerlendirmektedir (Glasser, 1976; Hausenblas ve Downs, 2002a). Egzersiz bağımlılığı; egzersiz rutininin bireyin kontrolünden çıkarak, egzersizden istenen 
etkinin sağlanması için egzersiz süresinin, sıklığının ve şiddetinin sürekli olarak arttırıması, aile ve arkadaşlara egzersiz yapmaktan vazgeçememe sebebiyle vakit ayıramama, sosyal aktivitelere katılmak yerine egzersiz yapma ve bireyin hayatını egzersiz alışkanlığı çerçevesinde yeniden düzenlenmesi olarak tanımlanmaktadır (Adams ve Kirkby, 2002).

Yurtdışında bu alanda yapılan bir çalışmada egzersiz bağımlıı̆ının kişilik özellikleri, psikolojik faktörler, fizyolojik faktörler, egzersiz tipi, cinsiyet ve egzersize katılım yılı gibi faktörlerle ilişkili olduğu belirtilmektedir (Hausenblas ve Downs, 2002b). Bağımlılığa neden olan faktörlerin belirlenmesi, bağımlılığın önlenmesi ve tedavi edilebilmesi için daha fazla araştırmaya intiyaç duyulmaktadır (Demetrovics ve Kurimay, 2008). Egzersiz bağımlılığının; gündelik olaylarla başa çıkabilmek için egzersize intiyaç duyma ve her gün egzersiz yapmadan yaşayamayacağına inanma, egzersizden uzak kaldığında psikolojik stres, gerginlik yaşama ve oluşan sağlık problemlerine rağmen egzersize devam etme isteği olduğu ve bunun mental bir rahatsızlık olduğu düşünülürse, üst düzey sporcuların egzersiz bağımlılı̆ı düzeylerinin belirlenmesi önemlidir. Bu bağlamda, bireyler üzerinde olumsuz etkileri olan egzersiz bağımlıı̆ı düzeyinin, üst düzey sporcuların bazı demografik değişkenleri açısından incelenmesi amaçlanmıştır.

\section{Yöntem}

Bu bölümde, araştırmada kullanılan model, çalışma grubu, veri toplama aracı, verilerin analizine ilişkin bilgilere yer verilmiştir.

\section{Araştırmanın Modeli}

Bu çalışmada, araştırma modellerinden nicel araştırma modeli benimsenmiştir. Nicel araştırmalarda olaylar arasındaki ilişkileri tanımlamak için sayısal veriler kullanır (Büyüköztürk ve ark., 2014). Araştırma, tarama modelinde betimsel bir araştırmadır. Tarama modelleri, geçmişte ya da halen var olan bir durumu var olduğu şekliyle betimlemeyi amaçlayan araştırmalara uygun bir modeldir (Büyüköztürk ve ark., 2014). Genel tarama modelleri, çok sayıda elamandan oluşan bir evrende, evren hakkında genel bir yargıya varmak amacı ile evrenin tümü ya da ondan alınacak bir grup örnek ya da örneklem üzerinde yapılan tarama düzenlemeleridir (Karasar, 2009). 


\section{Evren ve Örneklem}

Araştırmanın evrenini, 2018-2019 yılında, Türkiye Atletizm Federasyonu, Türkiye Güreş Federasyonu, Türkiye Ragbi Federasyonu ve Türkiye Basketbol Federasyonu'nda spora devam etmekte olan, kendi branşlarında milli takımda yer alan ve milli takım hazırlık kampında bulunan 66'sı takım, 94'ü bireysel branş üst düzey sporcuları oluşturmaktadır. Araştırmanın örneklem grubunu ise, 35 kadın, 125 erkek sporcu olmak üzere 160 üst düzey sporcu oluşturmaktadır. Seçilen örneklem grubunda yer alan katılımcılar, en az 5 yıldır profesyonel olarak spor yapmakta ve milli takımda yer almaktadır.

\section{Veri Toplama Aracı}

Araştırmada katılımcıların kişisel bilgilerini almak için araştırmacılar tarafından oluşturulan "Kişisel Bilgi Formu" ve Tekkurşun-Demir, Hazar ve Cicioğlu (2018) tarafından geliştirilen "Egzersiz Bağımlıığı Ölçeği (EBÖ)” kullanılmıştır. Ölçek, 17 madde ve 3 alt boyuttan oluşmakta ve ölçekte ters (olumsuz) madde bulunmamaktadır. Ölçeğin derecelendirilmesi 5'li likert tipi derecelendirme ile yapılmaktadır. Alt boyutlar incelendiğinde, birinci alt boyutun "Aşırı Odaklanma ve Duygu Değişimi” adı altında ilk 7 maddeden $(1,2,3,4,5,6,7)$ oluştuğu saptanmıştır. Tek başına bu alt boyut, ölçekteki egzersiz bağımlılığı değişkeninin \% 34,89'unu açıklamaktadır. İkinci alt boyut olan "Bireysel-Sosyal İhtiyaçların Ertelenmesi ve Çatışma"nın 6 maddeden $(8,9,10,11,12,13)$ oluştuğu tespit edilmiştir. Tek başına bu alt boyut, ölçekteki egzersiz bağımlılığı değişkeninin \% 13,06'sını açıklamaktadır. Üçüncü alt boyutun ise "Tolerans Gelişimi ve Tutku” adı altında 4 maddeden (14, 15, $16,17)$ oluştuğu ve tek başına üçüncü alt boyutun ölçekteki egzersiz bağımlılığı değişkeninin \% 6,65' ini açıkladığı saptanmıştır. Asıl ölçekte cronbach alpha değerleri "Aşırı Odaklanma ve Duygu Değişimi" alt boyutunda 0.83; "Bireysel-Sosyal İhtiyaçların Ertelenmesi ve Çatışma" alt boyutunda 0.79; "Tolerans Gelişimi ve Tutku" alt boyutunda ise 0.77 olarak tespit edilmiştir. Egzersiz Bağımlılığı Ölçeğinin örneklem grubu için güvenirliği test edilmiştir. Buna göre, Aşırı Odaklanma ve Duygu Değişimi alt boyutu Cronbach alfa değeri 0.86; Bireysel-Sosyal İhtiyaçların Ertelenmesi ve Çatışma alt boyutu Cronbach alfa değeri 0.74; Tolerans Gelişimi ve Tutku alt boyutu Cronbach alfa değeri 0.78 ve tüm alt boyutlar toplam puanı 0.87 'dir. Egzersiz Bağımlılığı Ölçeğinin normal grup puan aralığı 1-17, az riskli grup puan aralığı 18-34, risk grubu puan aralığı 35-51, bağımlı grup puan aralığı 52-69 ve 
yüksek grup puan aralığı 70-85 puan olarak değerlendirilmektedir (Tekkurşun Demir vd., 2018).

\section{Verilerin Analizi}

Çalışmadan elde edilen verilerinin istatistiksel analizi "Statistical Packagefor Social Sciences" (SPSS) Version 23 istatistik programı kullanılmıştır. Verilerin analizinde çarpıklık, basıklık değerlerinin -1 ile +1 aralığını aşması nedeniyle elde edilen verilere nonparametrik testler uygulanmıştır. Çalışmanın istatistiksel analizinde, değerlendirmeye alınan değişkenler, aritmetik ortalama $(\overline{\mathrm{x}})$, standart sapma (ss), sayı ve yüzde değerleri ile tanımlanmıştır. Çalışmada cinsiyete göre verilerin karşılaştırması Mann Whitney $U$ testi ile, eğitim durumuna göre verilerin karşılaştırmasında ise Krusal-Wallis testi uygulanmıştır. Anlamlılık $p<0.05$ olarak kabul edilmiştir.

Katılımcıların özelliklerinin belirtilmesinde tanımlayıcı istatistik, bağımsız iki grup arasındaki farkların karşılaştırılmasında Mann Whitney $U$ testi, ikiden fazla bağımsız grupların ortalama farklarının karşılaştırılmasında Kruskall Wallis testi, farkın hangi gruplar arasında olduğunu belirlemek içinse Dunn'sparametrik olmayan posthoc karşılaştırma testi uygulanmıştır. Katılımcıların yaş ve spor yaşı değişkeni ile ölçek alt boyut puanları ile toplam puan ortalamaları arasındaki ilişkinin tespit edilmesinde ise Spearman korelasyon testi kullanılmıştır.

\section{Bulgular}

Bu kısımda yapılan araştırma da elde edilen bulgular ve bu bulgulara ait yorumlar yer almaktadır. Tablo 1'de katılımcılara ait spor yaşı değişkeni ile egzersiz bağımlılığı ölçeği alt boyutları ve ölçek toplam puanları arasındaki ilişkiyi araştıran Spearman korelasyon testi sonuçları verilmiştir.

Tablo1. Katılımcıların Egzersiz Bağımlılığı Ölçeği Alt Boyutları ve Toplam Puanları İle Spor Yaşı Değişkeni Arasındaki İlişki

\begin{tabular}{lccccc}
\hline Değişken & $\begin{array}{c}\text { Aşırı Odaklanma ve } \\
\text { Duygu Değişimi }\end{array}$ & $\begin{array}{c}\text { Bireysel-Sosyal Ihtiyaçların } \\
\text { Ertelenmesi ve Çatışma }\end{array}$ & $\begin{array}{c}\text { Tolerans } \\
\text { Gelişimi ve } \\
\text { Tutku }\end{array}$ & $\begin{array}{c}\text { Toplam } \\
\text { Puan }\end{array}$ \\
\hline Spor & rho & $\mathbf{0 . 1 7}$ & 0.05 & -0.07 & 0.03 \\
Yaşı & $p$ & $\mathbf{0 . 0 2}^{*}$ & 0.52 & 0.32 & 0.64 \\
\hline${ }^{*} \mathrm{p}<0.05$ & & & &
\end{tabular}

Bulgular incelendiğinde katılımcıların spor yaşı ile Aşırı Odaklanma ve Duygu Değişimi alt boyutu arasında pozitif yönde ve düşük düzeyde istatistiksel olarak 
anlamlı bir ilişki tespit edilmiştir $(r=0.178, p<0.05)$. Diğer alt boyutlar açısından bakıldığında ise spor yaşı değişkeni ile aralarında istatiksel olarak anlamlı herhangi bir ilişki tespit edilememiştir $(p>0.05)$.

Tablo 2'de egzersiz bağımlıı̆ı ölçeği alt boyut ve toplam puan ortalamaları katıımcıların branş değişkenine göre karşılaştırılmıştır.

Tablo 2. Egzersiz Bağımlılığı Ölçeğinin Alt Boyut ve Toplam Puan Ortalamalarının Spor Branşları Değişkeni Bakımından Karşılaştırıması

\begin{tabular}{|c|c|c|c|c|c|c|c|}
\hline Ölçek & Branş & $\mathbf{N}$ & Ort. & S.S. & $\mathbf{U}$ & $\mathbf{Z}$ & p \\
\hline Aşırı Odaklanma ve Duygu Değişimi & $\begin{array}{l}\text { Bireysel } \\
\text { Takım }\end{array}$ & $\begin{array}{l}94 \\
66\end{array}$ & $\begin{array}{l}24.98 \\
26.33\end{array}$ & $\begin{array}{l}6.31 \\
6.43\end{array}$ & 2586.500 & -1.79 & 0.07 \\
\hline $\begin{array}{l}\text { Bireysel-Sosyal İhtiyaçların Ertelenmesi ve } \\
\text { Çatışma }\end{array}$ & $\begin{array}{l}\text { Bireysel } \\
\text { Takım }\end{array}$ & $\begin{array}{l}94 \\
66\end{array}$ & $\begin{array}{l}20.20 \\
18.59\end{array}$ & $\begin{array}{l}4.96 \\
5.97\end{array}$ & 2685.500 & -1.44 & 0.14 \\
\hline Tolerans Gelişimi ve Tutku & $\begin{array}{l}\text { Bireysel } \\
\text { Takım }\end{array}$ & $\begin{array}{l}94 \\
66\end{array}$ & $\begin{array}{l}14.07 \\
13.67\end{array}$ & $\begin{array}{l}3.36 \\
4.42\end{array}$ & 2697.000 & -0.47 & 0.63 \\
\hline Toplam Puan & $\begin{array}{l}\text { Bireysel } \\
\text { Takım }\end{array}$ & $\begin{array}{l}94 \\
66\end{array}$ & $\begin{array}{l}59.26 \\
58.59\end{array}$ & $\begin{array}{l}11.71 \\
13.57\end{array}$ & 3076.500 & -0.08 & 0.93 \\
\hline
\end{tabular}

${ }^{*} \mathrm{p}<0,05 ; H_{0}: \mu_{1}=\mu_{2}$

Buna göre; bireysel ve takım spor branşlarına ait ölçek alt boyutlarında 'Aşırı Odaklanma ve Duygu Değişimi' ile 'Bireysel-Sosyal İhtiyaçların Ertelenmesi ve Çatışma' puan ortalamalarına bakıldığında 'az risk' grubunda yer aldıkları, 'Tolerans Gelişimi ve Tutku' alt boyut puan ortalamasına bakıldığında ise 'normal' grupta yer aldıkları saptanmıştır. Grup ortalamaları arasındaki farkın önemli olup olmadığını test eden Mann-Whitney $U$ testi sonuçları incelendiğinde, grup ortalamaları arasındaki farkın istatistiksel olarak önemsiz olduğunu iddia eden sıfır hipotezinin herhangi bir boyut açısından reddedilemeyeceği görülmektedir $(p>0.05)$. Bu durumda ilgilenilen spor branşının hakkında bilgi edinilmek istenen boyutlar üzerinde istatistiksel olarak anlamlı bir etki yaratmadığı \%95 güvenilirlikle söylenebilir. Ölçek toplam puanları bakımından incelendiğinde her iki branş sporcularının da bağımlı grupta yer aldıkları görülmüştür. Tablo 3'te egzersiz bağımlılığı ölçeği alt boyut ve toplam puan ortalamaları katıımcıların cinsiyet değişkenine göre karşılaştııımıştır.

Tablo 3. Egzersiz Bağımlılığı Ölçeği Toplam ve Alt Boyut Puan Ortalamalarının Cinsiyet Değişkeni Bakımından Karşılaştııııması

\begin{tabular}{|c|c|c|c|c|c|c|c|}
\hline Ölçek & Cinsiyet & $\mathbf{N}$ & Ort. & SS & $U$ & $\mathbf{Z}$ & $\mathbf{P}$ \\
\hline Aşırı Odaklanma ve Duygu Değişimi & $\begin{array}{l}\text { Kadın } \\
\text { Erkek }\end{array}$ & $\begin{array}{l}35 \\
125\end{array}$ & $\begin{array}{l}26.17 \\
25.36\end{array}$ & $\begin{array}{l}5.63 \\
658\end{array}$ & 2093.500 & -0.38 & 0.69 \\
\hline $\begin{array}{l}\text { Bireysel-Sosyal İhtiyaçların Ertelenmesi } \\
\text { ve Çatışma }\end{array}$ & $\begin{array}{l}\text { Kadın } \\
\text { Erkek }\end{array}$ & $\begin{array}{l}35 \\
125\end{array}$ & $\begin{array}{l}19.69 \\
19.50\end{array}$ & $\begin{array}{l}4.71 \\
5.64\end{array}$ & 2141.500 & -0.19 & 0.84 \\
\hline Tolerans Gelişimi ve Tutku & $\begin{array}{l}\text { Kadın } \\
\text { Erkek }\end{array}$ & $\begin{array}{l}35 \\
125\end{array}$ & $\begin{array}{l}13.63 \\
13.98\end{array}$ & $\begin{array}{l}4.05 \\
3.77\end{array}$ & 2105.500 & -0.34 & 0.73 \\
\hline Toplam Puan & $\begin{array}{l}\text { Kadın } \\
\text { Erkek }\end{array}$ & $\begin{array}{l}35 \\
125\end{array}$ & $\begin{array}{l}59.49 \\
58.84\end{array}$ & $\begin{array}{l}11.72 \\
12.72\end{array}$ & 2158.000 & -0.12 & 0.90 \\
\hline
\end{tabular}

${ }^{\star} \mathrm{p}<0,05 ; H_{0}: \mu_{1}=\mu_{2}$ 
Buna göre, kadın ve erkeklere ait ölçek alt boyutlarından 'Aşırı Odaklanma ve Duygu Değişimi' ile 'İhtiyaçların Ertelenmesi ve Çatışma'nın puan ortalamalarına göre katılımcıların 'az risk' grubunda yer aldıkları, 'Tolerans Gelişimi ve Tutku' alt boyutu puan ortalamasına bakıldığında 'normal' grupta yer aldıkları saptanmıştır. Grup ortalamaları arasındaki farkın önemli olup olmadığını test eden Mann-Whitney $U$ testi incelendiğinde, grup ortalamaları arasındaki farkın istatistiksel olarak önemsiz olduğunu iddia eden sıfır hipotezinin herhangi bir boyut açısından reddedilemeyeceği görülmektedir $(p>0.05)$. Bu durumda cinsiyetin hakkında bilgi edinilmek istenen boyutlar üzerinde istatistiksel olarak anlamlı bir etki yaratmadığı \% 95 güvenilirlikle söylenebilir. Tablo 4'te egzersiz bağımlılığı ölçeği alt boyut ve toplam puan ortalamalarının katıımcıların maddi gelir durumuna göre istatistiksel olarak anlamlı bir düzeyde farklılaşıp farklılaşmadığını test eden Kruskal-Wallis testi sonuçları ve grup ortalamalarına ilişkin bilgiler verilmiştir.

Tablo 4. Egzersiz Bağımlıı̆ı Ölçeği Toplam ve Alt Boyut Puan Ortalamalarının Maddi Gelir Değişkeni Bakımından Karşılaştıııması

\begin{tabular}{llccccc}
\hline Ölçek & Maddi Gelir & N & Ort. & Sıra ort. & $\chi^{2}$ & P \\
\hline \multirow{3}{*}{ Aşırı Odaklanma ve Duygu } & 0-999 TL(1) & 50 & 25.94 & 81.13 & & \\
Değişimi & 1000-1999TL(2) & 40 & 25.00 & 71.60 & 5.52 & 0.13 \\
& 2000-2999TL(3) & 26 & 24.31 & 72.04 & & \\
& 3000TL ve üstü(4) & 44 & 26.30 & 92.88 & & \\
\hline \multirow{3}{*}{ Bireysel-Sosyal İhtiyaçların } & 0-999 TL(1) & 50 & 20.24 & 85.16 & & \\
Ertelenmesi ve Çatı̧̧ma & 1000-1999TL(2) & 40 & 20.25 & 85.89 & 2.52 & 0.47 \\
& 2000-2999TL(3) & 26 & 19.15 & 76.67 & & \\
& 3000TL ve üstü(4) & 44 & 18.32 & 72.57 & & \\
Tolerans Gelişimi ve Tutku & 0-999 TL(1) & 50 & 14.14 & 83.59 & & \\
& 1000-1999TL(2) & 40 & 13.58 & 75.18 & \multirow{2}{*}{0.70} & 0.63 \\
& 2000-2999TL(3) & 26 & 14.54 & 88.23 & & \\
& 3000TL ve üstü(4) & 44 & 13.57 & 77.26 & & \\
\hline \multirow{5}{*}{ Toplam puan } & 0-999 TL(1) & 50 & 60.32 & 85.35 & & \\
& 1000-1999TL(2) & 40 & 58.83 & 79.26 & \multirow{2}{*}{0.82} & 0.84 \\
& 2000-2999TL(3) & 26 & 58.00 & 78.12 & & \\
\hline 3000TL ve üstü(4) & 44 & 58.18 & 77.52 & & \\
\hline
\end{tabular}

*p<0,05; $H_{0}: \mu_{1}=\mu_{2}=\cdots \mu_{n}$

Buna göre; katılımcıların, ölçek alt boyutlarından 'Aşırı Odaklanma ve Duygu

Değişimi' ile 'Bireysel-Sosyal İhtiyaçların Ertelenmesi Ve Çatışma' puan ortalamasına göre 'az risk' grubunda, 'Tolerans Gelişimi ve Tutku' alt boyut puanlarına bakıldığında 'normal' grupta oldukları görülmüştür. Ölçek toplam puan sonuçlarına bakıldığında katılımcıların, maddi gelir değişkenine göre 'bağımlı' grupta oldukları tespit edilmiştir. Tablodaki Kruskal-Wallis testi istatistikleri incelendiğinde ise maddi gelir grupları bakımından ölçek alt boyut ve toplam puan ortalamaları arasında istatiksel olarak 
anlamlı farklılıklar olmadığını iddia eden hipotezin \%95 güvenilirlikle tüm gruplar için reddedilemeyeceği görülmektedir ( $p>0.05)$.

\section{Tartışma ve Sonuç}

Egzersiz bağımlığının bireyler üzerinde oluşturabileceği zararlar göz önünde bulundurulduğunda, üst düzey sporcuların bağımlılık düzeylerinin incelenmesi, başarıları ve sosyal yaşamları üzerinde etkisi olacağı düşünülmüştür. Bu bağlamda 94'ü bireysel (atletizm, güreş), 66'sı takım (basketbol, amerikan futbolu) sporcusu olmak üzere araştırmaya toplam 160 üst düzey sporcu katılmıştır.

Araştırmanın ilk bulgusunda üst düzey sporcuların, egzersiz bağımlılığı ile spor yaşı arasında Aşırı Odaklanma ve Duygu Değişimi' alt boyutunda anlamlı bir ilişki saptanmıştır. Bu bağlamda spor yaşı ile 'Aşırı Odaklanma ve Duygu Değişimi' ölçek alt boyutu arasında istatiksel anlamda pozitif yönde düşük ilişki tespit edilmiştir. Buna göre katılımcıların spor yaşı arttıkça egzersiz yapma isteklerinin ve egzersizden keyif alma düzeyinin arttığı söylenebilir. Buna neden olarak üst düzey sporcuların yaşamlarında karşılaşmış oldukları herhangi bir sorun karşısında, egzersiz yapmanın onları mutlu hissettirerek, egzersizin alışkanlık haline geldiği ve yaşam içinde oluşturulan egzersiz düzeninin zaman içinde bağımlılığa dönüşebildiği söylenebilir. Araştırmanın diğer alt grupları olan, 'Bireysel-Sosyal İhtiyaçların Ertelenmesi ve Çatışma' ile 'Tolerans Gelişimi ve Tutku' alt boyutları puanı incelendiğinde istatiksel açıdan anlamlı bir ilişki bulunamamıştır. Araştırma sonucuna paralel olarak Çakır'ın (2019), üniversite öğrencilerinin egzersiz bağımlılık düzeylerini incelediği araştırmasında düzenli egzersizin, egzersiz bağımlılığını etkileyeceği sonucuna ulaşmıştır. Cicioğlu vd., (2019) 'Elit Düzeyde Sporcular ile Spor Bilimleri Fakültesi Öğrencilerinin Egzersiz Bağımlılığı Düzeyleri'ni belirlemeye yönelik yapmış olduğu çalışmada da düzenli egzersizin egzersiz bağımlılığını etkilediği sonucuna ulaşılmıştır. Kagan, (1987) 'Bağımlııı ve Kişilik Faktörleri' adlı çalışmasında egzersize katılım yılı fazla olanların bağımlılık puanının oldukça yüksek çıktığını tespit etmiştir. Namlı vd., (2018) Spor Bilimleri Fakültesi öğrencilerinin akademik odaklanma düzeylerini belirlemeye yönelik kickbox, taekwondo ve muaytai sporcuları üzerinde yapmış oldukları araştırmada düzenli egzersizin egzersiz bağımlılığı için etkili olduğu sonucuna ulaşmıştır. Polat ve Şimşek (2015)'in Eskişehir'de bulunan spor merkezlerindeki düzenli olarak egzersiz yapan 242 katılımcının egzersiz bağımlılıklarını incelediği çalışmasında egzersiz sıklığına göre egzersiz bağımlılığı arasında anlamlı farklılaşma bulunmuştur. Bir başka araştırmada ise Costa vd., 
(2012) egzersiz sıklığı, günlük egzersiz süresi ve spor yaşının egzersiz bağımlıı̆ının ortaya çıkmasında etkili olabileceği sonucuna ulaşmıştır. Nitekim, egzersiz sıkığı ve egzersiz süresini kontrol edememe halinin devam etmesi sonucunda egzersiz bağımlılı̆ı gibi fizyolojik, psikolojik ve sosyal sorunlar meydana geldiği bilinmektedir (Masters ve Lambert, 1989).

$\mathrm{Bu}$ araştırmanın bir diğer bulgusunda, bireysel ve takım spor branşlarına ait ölçek alt boyut ve toplam puan ortalamaları arasında istatiksel açıdan fark bulunmamıştır. Ancak, bireysel ve takım spor branşlarına ait EBÖ alt boyutları ortalamasına bakıldığında, 'Aşırı Odaklanma ve Duygu Değişimi ile Bireysel-Sosyal İhtiyaçların Ertelenmesi ve Çatışma' alt boyutlarında her iki branşın 'az risk' grubunda olduğu, 'Tolerans Gelişimi ve Tutku' alt boyutunda ise 'normal' grupta yer aldıkları görülmüştür. Her iki branşın ölçek toplam puanlarına bakıldığında 'bağımlı' grupta yer aldıkları tespit edilmiştir. Buna neden olarak, bireysel ve takım sporcularının kendi branşlarında başarılı olmak için daha çok egzersiz yapmaya intiyaç duydukları ve yapılan egzersiz sonucunda gerek performans artışları gerekse sosyal çevre tarafından beğenilmeleri bireyleri egzersize daha çok zaman ayırmaya yönelterek bu durumun sonucu olarak egzersiz bağımlıı̆ının ortaya çıktığı söylenebilir. Araştırma sonucuna paralel olarak, atletler üzerinde yapılan araştırmalarda, kadınların erkelerden daha yüksek düzeyde egzersiz bağımlıı̆ına sahip olduğunu belirten çalışmalar yer almaktadır (Hailey ve Bailey, 1982; Pierce, Rohaly ve Fritchley, 1997). Ancak; Smith ve Hale, (2005); egzersiz bağımlıı̆ının sıklıkla koşucularda bulunma kavramına karşın, sadece koşuculara özgü olmayıp vücut geliştirme gibi birçok farklı spor dalında da bağımlıı̆ın görülebileceğini bildirmiştir. Costa vd., (2012) düzenli olarak koşu $(\% 21,7)$ ve vücut geliştirme $(\% 25)$ egzersizi yapan bireylerin egzersiz bağımlısı grubunda yer aldığını saptamıştır.

Araştırmanın diğer bulgusunda, kadın ve erkeklere ait ölçek alt boyut ve toplam puan ortalamaları arasında istatiksel anlamda farklılık bulunmamıştır. Ölçek alt boyutların ortalaması incelendiğinde; 'Aşırı Odaklanma ve Duygu Değişimi ile Bireysel-Sosyal İhtiyaçların Ertelenmesi ve Çatışma' alt boyutlarının ortalamasında kadın ve erkek sporcuların 'az risk' grubunda olduğu, 'Tolerans Gelişimi ve Tutku' alt boyutunda ise 'normal' grupta yer aldıkları görülmektedir. Üst düzey sporcuların, kadın ve erkek ölçek toplam puanlarına göre 'bağımlı' grupta yer aldıkları tespit edilmiştir. Genellikle ideal kadın figürü yağsız ve zayıf, ideal erkek figürü ise kaslı ve yapılı olarak algılanır (Hausenblas ve Fallon, 2002). Bu algı göz önünde bulundurularak, kadın ve erkek sporcuların egzersize yönelmelerinde görünümün 
büyük önem taşıdığı söylenebilir. Araştırmanın sonucuna paralel olarak, Bingöl,(2015), Muğla ili ve çevre illerde Boks, Muay Thai, Güreş, Taekwondo, Voleybol, Basketbol, Hentbol ve Futbol branşlarında en az 5 yıl düzenli olarak spor yapan 777 lisanslı sporcuların egzersiz bağımlılık ve psikolojik sağlamlık düzeylerinin incelendiği çalışmada, bireylerin egzersiz bağımlılık düzeyleri ile cinsiyet değişkeni arasında istatistiksel bakımdan anlamlı farklılık tespit edilmemiştir. Çetin vd., (2020) yapmış oldukları "The Examination of the Relationship Between Exercise Addiction and Performance Enhancement in Elite Athletes" isimli araştırmada da araştırma bulgularına benzer olarak kadın ve erkeklerin benzer düzeyde egzersiz bağımlılığı puanına sahip olduğu ve bu puanlar arasında anlamlı farklılık olmadığı saptanmıştır. Cicioğlu vd. (2019)'nin, 'Elit Düzeyde Sporcular ile Spor Bilimleri Fakültesi Öğrencilerinin Egzersiz Bağımlılığı Düzeyleri'ni belirlemeye yönelik yapmış olduğu çalışma sonucunda, cinsiyet değişkeni üzerinde yapılan değerlendirmede elit erkek sporcuların egzersiz bağımlılığı düzeylerinin, elit kadın sporculara göre istatistiksel açıdan anlamlı düzeyde yüksek olduğu bulunmuştur. Costa ve Hausenblas (2013) araştırmasında, egzersiz bağımlılığı riski altında olduğunu bildiren erkek yetişkinlerin (25-44 yaş) sayısının, genç erkek yetişkinlerden (18-24 yaş) daha yüksek olduğunu, kadınlarda ise yaş gruplarına göre hiçbir fark bulunmadığını bildirmiştir.

Araştırmada, katılımcıların maddi gelir düzeylerine ait ölçek alt boyut ve toplam puan ortalamaları arasında anlamlı farklılık bulunmuştur. Katılımcıların maddi gelir düzeylerine göre, EBÖ alt boyutlarından 'Aşırı Odaklanma ve Duygu Değişimi' ile 'Bireysel-Sosyal İhtiyaçların Ertelenmesi ve Çatışma' puan ortalamasına göre 'az risk' grubunda, 'Tolerans Gelişimi ve Tutku' alt boyut puanlarına bakıldığında 'normal' grupta oldukları tespit edilmiştir. Katılımcıların ölçek toplam puan sonuçlarına bakıldığında maddi gelir değişkenine göre 'bağımlı' grupta oldukları tespit edilmiştir. Buna sebep olarak, katılımcıların maddi gelir düzeylerinin egzersize yönelmelerinde etkin bir rol oynamadığı, sporcuların egzersiz yaparken almış oldukları hazzın maddi gelirlerinden daha fazla önem taşıdığı söylenebilir. Yapılan literatür taramasında katılımcıların gelir düzeylerine yönelik çalışmalar yer almaktadır. Bingöl (2015), farklı branşlardaki sporcuların egzersiz bağımlılık düzeylerini incelediği çalışmasında katılımcıların yaklaşık olarak \% 19,3' ü 500-1000 tl, \%26,9'u 1001-1500 tl, \%29,3'ü 1501-2000 tl, \%24,5'i ise 2001 tl ve üstünde gelire sahip oldukları tespit edilmiştir. Tekkurşun-Demir ve Türkeli, (2019) spor bilimleri fakültesinde öğrenim gören öğrencilerin egzersiz bağımlılığı düzeylerini incelediği araştırmada, 
katılımcıların aylık gelirine göre, egzersiz bağımlıı̆ı arasında anlamlı farklıık görülmemiştir.

Sonuç olarak, haftanın en az 4 günü düzenli olarak spor yapan, takım ve bireysel branşlardaki üst düzey sporcuların; Demir ve ark. (2018)'nın geliştirdiği 'Egzersiz Bağımlılık Ölçeği' kullanarak yapılan analizde, egzersiz bağımlıı̆ı ölçeği alt boyutları toplam puanlarına bakıldığında 'bağımlı' grupta yer aldıkları saptanmıştır. Bu bağlamda ortaya çıkan egzersiz bağımlılığı, profesyonel anlamda spor yapan sporcular için önemli bir sorun oluşturduğu söylenebilir. Sporcuların bağımlılık seviyesinin artmasıyla oluşacak fiziksel, sosyal ve psikolojik herhangi bir sorun yapmış oldukları branşlarındaki başarıyı olumsuz yönde etkileyebilir. Bu durum göz önünde bulundurulduğunda, yapılacak olan çalışmaların daha geniş örneklem grubuna uygulanması, farklı branşlar ve sadece üst düzey sporcular için değil sağlık için spor yapan tüm bireyler üzerinde de araştırma yapılmasının faydalı olabileceği düşünülmektedir.

\section{Kaynaklar}

Adams, J. ve Kirkby, R.J. (2002). Excessive exercise as an addiction: A review. Addiction Research and Theory, 10, 415-437.

Adams, J.M., Miller, T.W. ve Kraus, R.F. (2003). Exercise dependence: diagnostic and therapeutic issues for patients in psychotherapy. Journal of Contemporary Psychotherapy, 33(2), 93-107.

Büyüköztürk, Ş., Çakmak, E. K., Akgün, Ö. E., Karedeniz, Ş. ve Demirel, F. (2014). Bilimsel araştırma yöntemleri. (18. Baskı). Ankara: Pegem Akademi.

Cicioğlu, H. İ., Tekkurşun-Demir, G., Bulgay, C. ve Çetin, E. (2019). Elit düzeyde sporcular ile spor bilimleri fakültesi öğrencilerinin egzersiz bağımlılığı düzeyleri. Bağımlılık Dergisi - Journal of Dependence, 20(1), 12-20.

Costa, S., Cuzzocrea, F., Hausenblas, H.A., Larcan, R. ve Oliva, P. (2012). Psychometric examination and factorial validity of the exercise dependence scale-revised in Italian exercisers. Journal Behav Addict, 1(4), 186-190.

Costa, S., Hausenblas, A. H., Oliva, P., Cuzzocrea, F. ve Larcan, R. (2013). The Role of Age, Gender, Mood States and Exercise Frequency on Exercise Dependence. Journal of Behaviour Addicttions, 2(4), 216-223.

Cronbach, L. J. (1941). The reliability of ratio scores. Educational and Psychological Measurement, 1(1), 269-277. 
Cronbach, L.J. (1951). Coefficient alpha and the internal structure of tests. Psychometrika, 16(3), 297-334.

Çakır, E. (2019). The examination of exercise addiction levels of university students stundying in helath field. Journal Of Eduction and Traning Studies, 7(3), 1-5.

Çetin, E., Bulğay, C., Demir, G. T., Cicioğlu, H. I., Bayraktar, I., ve Orhan, Ö. (2020). The Examination of the Relationship Between Exercise Addiction and Performance Enhancement in Elite Athletes. International Journal of Mental Health and Addiction, 1-12.

De Coverley-Veale, D.M.W. (1987). Exercise dependence. British Journal Of Addiction, 82(7), 735-740.

Demetrovics, Z. ve Kurimay, T. (2008). Exercise addiction: A literature review. Psychiatr Hung, 23, 129-141.

Glasser, W. (1976). Positive addiction. USA: Harper and Row.

Griffiths, M. (2000). Does Internet and computer "addiction" exist? Some case study evidence. CyberPsychology and Behavior, 3(2), 211-219.

Hailey, B. J. ve Bailey, L. A. (1982). Negative addiction in runners: A quantitative aproach. Journal of Sport Behavior, 5, 150-154.

Hausenblas, A. H. ve Downs, S. D. (2002a). How much is toomuch? The development and validation of the exercise dependence scale. Psychology and Health, 17(4), 387-404.

Hausenblas, A. H. ve Downs, S. D. (2002b). Exercise dependence a systematic review. Psychology of Sportand Exercise, 3, 89-123.

Hausenblas, H.A. ve Downs, D.S. (2000). How much is too much? The development and validation of the exercise dependence scale. Psychol Health, 17, 387-404.

Hausenblas, H.A. ve Fallon, E.A. (2002). Relationship among body image, exercise behavior, and exercise dependence symptoms. Inc. Int Journal Eat Disord, 32, 179-185.

Kagan, D.M. (1987). Addictive personality factors. Journal of Sport Medicine, 121, 553-538.

Klein, S. (2005). Obezite tedavisi için para ödemek para ediyor mu? Türkiye Klinikleri, 1(2): $82-82$

Karasar, N. (2009). Bilimsel Araştırma Yöntemleri. Ankara: Nobel.

Masters, K.S ve Lambert, M.J. (1989). The relations between cognitive coping strategies, reasons for running, injury, and performance of marathon runners. Journal Sport Exerc Psycholg, 11(2), 161-170. 
Namlı, S., Demir, G.T. ve Cicioğlu, H.I. (2018). Spor Bilimleri Fakültesi öğrencilerinin akademik odaklanma düzeyleri. Beden Eğitimi ve Spor Bilimleri Dergisi, 20(4), 43-51.

Orford, J. (1985). Excessive appetites: A psychological view of addictions. Chichester: Wiley.

Pierce, E. F, Rohaly, K. A. ve Fritchley, B. (1997). Sex differences on exercise dependence for men and women in a marathon road race. Percept Motor Skills, 84, 991-994.

Polat, C. ve Şimşek K.Y. (2015). Spor merkezlerindeki bireylerin egzersiz bağımlılığı düzeylerinin incelenmesi: Eskişehir İli Örneği. Akademik Sosyal Araştırmalar Dergisi, 3(15), 354-369.

Smith, D. ve Hale, B. (2005). Exercise-dependence in bodybuilders: Antecedents and reliability of measurement. Journal Sports Medicine Phys Fitness, 45, 401-408.

Szabo, A. (1998). Studying the psychological impact of exercise deprivation: Are experimental studies hopeless? Journal of Sport Behavior, 21, 139-147.

Szabo, A. (2000). Physical activity and psychological dysfunction. S. Biddle, K. Fox, \& S. Boutcher, (Ed.), Physical activity and psychological well-being içinde, (s.130-153). London: Routledge.

Tekkurşun-Demir, G. ve Türkeli, A. (2019). Spor bilimleri fakültesi öğrencilerinin egzersiz bağımlılığı ve zihinsel dayanıklıık düzeylerinin incelenmesi. Spor Bilimleri Araştırmaları Dergisi, 4(1), 9-24.

Tekkurşun-Demir, G., Hazar, Z. ve Cicioğlu, H. İ. (2018). Egzersiz bağımlıı̆ı ölçeği: Geçerlilik ve güvenirlilik çalışması. Kastamonu Eğitim Dergisi, 26(3), 865-874.

Yates, A. (1991). Compulsive exercise and the eating disorders: Toward an Integrated theory of activity. New York: Brunner/Mazel 